\title{
The Perils of Exchange: Karma, Kingship and Templecraft in
}

\section{Tibet}

Martin A. Mills

\section{Citer ce document / Cite this document :}

Mills Martin A. The Perils of Exchange: Karma, Kingship and Templecraft in Tibet. In: Cahiers d'Extrême-Asie, vol. 24, 2015. Kingship, Ritual, and Narrative in Tibet and the Surrounding Cultural Area / Royauté, rituel et narration au Tibet et dans l'aire culturelle alentour. pp. 189-209;

doi : https://doi.org/10.3406/asie.2015.1320

https://www.persee.fr/doc/asie_0766-1177_2015_num_24_1_1320

Fichier pdf généré le 06/02/2019 


\section{Résumé}

Le concept de karma commun ou partagé reste un aspect largement inexploré dans les études bouddhiques. Toutefois, cette notion a un impact sur les valeurs tibétaines d'offrande, d'échange et sur le concept de moralité dans l'acte de gouverner. Les écrivains religieux tibétains ont généralement affirmé l'organisation articulée et, par extension " trans-personnelle », des actions morales et donc des conséquences karmiques. Ces liens « transpersonnels " sont générés par des relations de responsabilité, d'héritage commun et d'échange hiérarchique. Dans la sphère religieuse, une ambivalence morale envers l'offrande, l'échange et les parrainages de la part des bouddhistes vertueux est apparue. En effet, l'acceptation de cadeaux et d'offrandes est alors vue comme apportant certains rapprochements moraux qui sont considérés comme antithétiques à la pureté spirituelle. En ce qui concerne le gouvernement, cette logique était appliquée de façon proportionnelle aux responsabilités des souverains en tant que propriétaires de terre et en tant que destinataires des territoires conquis. De la sorte, les souverains et les institutions étatiques sont présentés comme étant au centre d'une « mer de karma » qui les relie au bien-être de leurs sujets. Dans le sillage de 1642, cette conception gêna la fondation de l'état du Ganden Podrang des Dalai Lama, qui devenaient à la fois souverains et maîtres spirituels. Cet article identifie trois méthodes principales par lesquelles la pureté spirituelle des Dalai Lamas en tant que souverains fut maintenue comme principe du pouvoir légitime : premièrement, la séparation entre l'état et le souverain ; deuxièmement, la protection rituelle du souverain des impuretés nécessaires liées aux actions séculières, en particulier à la guerre ; troisièmement, l'érection apotropaïque des temples (par exemple le Palais Blanc du Potala) afin de bloquer les conséquences karmiques de la guerre. Dans le cadre de la philosophie politique tibétaine, l'état bouddhique était donc loin d'être dépourvu de complexité : ces problèmes concernaient la question de l'agencement moral et de la pureté du souverain, mais étaient résolus dans des termes pratiques rituels plutôt qu'idéologiques. 


\title{
The Perils of ExChange: Karma, Kingship and Templecraft in Tibet
}

\author{
Martin MiLls
}

\begin{abstract}
Le concept de karma commun ou partagé reste un aspect largement inexploré dans les études bouddbiques. Toutefois, cette notion a un impact sur les valeurs tibétaines d'offrande, d'échange et sur le concept de moralité dans l'acte de gouverner. Les écrivains religieux tibétains ont généralement affirmé l'organisation articulée et, par extension " trans-personnelle ", des actions morales et donc des conséquences karmiques. Ces liens " transpersonnels » sont générés par des relations de responsabilité, d'béritage commun et d'échange biérarchique. Dans la sphère religieuse, une ambivalence morale envers l'offrande, l'échange et les parrainages de la part des bouddhistes vertueux est apparue. En effet, l'acceptation de cadeaux et d'offrandes est alors vue comme apportant certains rapprochements moraux qui sont considérés comme antithétiques à la pureté spirituelle. En ce qui concerne le gouvernement, cette logique était appliquée de façon proportionnelle aux responsabilités des souverains en tant que propriétaires de terre et en tant que destinataires des territoires conquis. De la sorte, les souverains et les institutions étatiques sont présentés comme étant au centre d'une "mer de karma " qui les relie au bien-être de leurs sujets. Dans le sillage de 1642, cette conception gêna la fondation de l'état du Ganden Podrang des Dalai Lama, qui devenaient à la fois souverains et maîtres spirituels. Cet article identifie trois méthodes principales par lesquelles la pureté spirituelle des Dalai Lamas en tant que souverains fut maintenue comme principe du pouvoir légitime : premièrement, la séparation entre l'état et le souverain; deuxièmement, la protection rituelle du souverain des impuretés nécessaires liées aux actions séculières, en particulier à la guerre; troisièmement, l'érection apotropaïque des temples (par exemple le Palais Blanc du Potala) afin de bloquer les conséquences karmiques de la guerre. Dans le cadre de la philosophie politique tibétaine, l'état bouddhique était donc loin d'être dépourvu de complexité : ces problèmes concernaient la question de l'agencement moral et de la pureté du souverain, mais étaient résolus dans des termes pratiques rituels plutôt qu’idéologiques.
\end{abstract}

\section{Introduction}

Since the invasion of Tibet by Mao's forces in 1950 and the subsequent flight into exile of the Fourteenth Dalai Lama and his government, the question of the "unity" of the Tibetan people has been raised again and again, not least by Tibetans themselves. In addressing this issue, the most usual approach is to deal with the question of Tibetan unity from the classical sociological perspectives of ethnicity 
and nationalism - that is, from the view that inasmuch as Tibetan unity exists, it is constituted in shared culture, whether that be of language, kinship, religion, law or political affiliation. ${ }^{2}$

Amidst these, religion - in this case, Buddhism - is often presented as both the defining shared aspect, and simultaneously the weakest link. Despite being recognized as one of the defining shared feature of Tibetan peoples (more recently, in conjunction with its sibling religion Bön), many have argued that Buddhist monastic and sectarian affiliation have largely served to separate Tibetans rather than unite them. What is shared is not necessarily what unites. This accusation is usually focused around the view that Buddhist doctrine-precisely as a consequence of its universalist and individualistic nature-lacks the means for mobilizing communal political or even religious solidarities.

Not all agree, however. Samdhong Rinpoché (Zam gdong rin po che)— the last prime minister of the Fourteenth Dalai Lama's exiled government from 200I to 20II - argued forcefully that Tibetan refugees had a strong moral imperative to support their fellow Tibetans within Tibet on account of their shared, or communal, karma (spyi mtbun phyi’i las):

Karmic responsibility means that we believe in collective karma and individual karma. You and I have absolutely individual karma which has nothing to do with each other, but we [also] have a lot of collective karma. Due to collective karma, we are talking; due to collective karma, we are sitting in one room. This room is not my private property, not your private property, but belongs to a pre-sentient being that uses this space. So that is collective karma. So someone born as Tibetan, in Tibet, or has Tibetan parents, their collective karma belongs to the Tibetan people. Their collective karma also belongs to the entire universe, but their collective karma has a great deal to do with the Tibetan people, so therefore we have a karmic relationship. ${ }^{3}$

Samdhong Rinpoché's comments point towards a largely ignored stratum in Tibetan thinking about the connection between people at both the everyday and the elite level. This substrate is that of the "karmic inter-relationship" (rten 'brel) and it combines together notions of social inter-connectedness, exchange and inheritance, and kingly and religious responsibility in a single indigenous field of discourse. It is this field of discourse that in many ways represents an indispensable backdrop to Tibetan understandings of the "moral economy of the state".

It is, however, more than simply a field of discourse, but a field of specific actions, and most particularly actions that relate persons together, in particular exchanges.

I. Georges Dreyfus, "Cherished Memories, Cherished Communities: Proto-Nationalism in Tibet," in The History of Tibet, vol. 2, ed. Alex McKay (London: Routledge, 2003), 492-522; Samten Karmay, "The Exiled Government and the Bonpo Community in India," in The Arrow and the Spindle: Studies in History, Myths, Rituals and Beliefs in Tibet, ed. Samten Karmay (Kathmandu: Mandala Book Point, 1998), 532-36; Ronald Schwartz, Circle of Protest: Political Ritual in the Tibetan Uprising (London: Hurst \& Co., 1994); Tsering Shakya, "Whither the Tsampa-Eaters?" Himal 6, no. 5 (1993): 8-II.

2. Shakya, "Whither the Tsampa-Eaters?"; Samten Karmay, "Mountain Cult and National Identity in Tibet," in The Arrow and the Spindle, 423-3I.

3. Samdhong Rinpoché, interview with author, Dharamsala, March 2I, 2012. 
From the earliest days of anthropology, Marcel Mauss argued that gift exchange constituted a "total prestation" - that the gift asserted and embodied both the nature of the relationship between the giver and the receiver, and the status and personhood of both. ${ }^{4}$ Moreover, Mauss argued that all such exchanges carried with them a moral valence as a consequence: that different forms of exchange of the same objects - passing on inheritance to a descendent versus selling the family silver, for example-have different moral connotations. In this sense, economies-including the economies that surround and form states - are intrinsically moral rather than the purely rational and bureaucratic redistribution of commodities.

What follows is the initial presentation of a case demanding the attention of scholars of religion and political historians both: that notions of communal and shared karma imply moral solidarities and boundaries that have shaped Tibetan understandings of legitimate governance. It is not, as yet, a detailed historical account of the development of those ideas, but rather the presentation of a lens through which much Tibetan political history may be viewed. By way of a comparison, we can (and many historians have) look at much of post-r6th-century western European political history through the lens of the developing idea of "the will of the people"-now while this may not be a historical reality in itself, it constitutes an emerging set of ideas, one that began in the political theology of early modern Christian kingship, 5 but later developed into several distinct, post-monarchical criteria of secular democratic governance. While these European ideas of legitimate governance have been extensively studied, periodised and mapped, the study of an equivalent (but distinct) Tibetan history of ideas remains in its infancy; indeed, in many respects, unborn, largely because we have been so intent on looking at Tibetan history through our own constitutional lenses of corporations, sovereignties, ethnicities and nationalisms.

\section{Karma and Moral Action}

The idea of individual karma is certainly familiar to most Western students of Buddhism, but ideas of communal karma receive less attention, and are often regarded as contentious. After all, does not as relatively straightforward a document as the Dhammapada state:

By oneself alone is evil done,

By oneself is one defiled,

By oneself is evil left undone,

By oneself alone is evil purified;

Both purity, impurity depend upon oneself

And nobody is found who can purify another.

4. Marcel Mauss, “Essai sur le don,” L'Année Sociologique (1925).

5. Ernst Kantorowicz, The King's Two Bodies (Princeton: Princeton University Press, 1957).

6. Charles E. Keyes \& Valentine Daniel, "Merit-Transference in the Kammatic Theory of Popular Theravada Buddhism," in Karma: An Anthropological Inquiry, ed. Charles E. Keyes \& Valentine Daniel (Berkeley: University of California Press, 1983), 270. 
Tibetan writers have had quite a lot to say on this matter over time, and are moreover relatively unified in what they have to say. There is in particular general agreement that meritorious actions are certainly possible on behalf of others, and therefore that some understanding of "communal karma" can provisionally be put forward. At the same time, in theory few if any of them would disagree with or challenge the logic of the Dhammapada. ${ }^{7}$ Thus, in his Lamrim chenmo (Lam rim chen mo, The Great [Treatise on] the Stages of the Path) - the central Geluk text on ethical training-Tsongkhapa (Tsong kha pa; 1357-I419) argues:

If you have not accumulated the karma that is the cause for an experience of happiness or suffering, you will in no way experience the happiness or suffering that is its effect. Those who enjoy the fruits of the innumerable collections amassed by the Teacher need not have accumulated all of the causes of these effects, but they do need to accumulate a portion. The actions you have done do not perish. Those who have done virtuous and non-virtuous actions create pleasant and unpleasant effects. As Udbhatasiddhasvamin's Praise of the Exalted One says:

"The brahmins say that virtue and sin, May transfer to others-like giving and receiving a gift.

You [O Buddha] taught that what one has done does not perish

And that one does not meet with the effects of what one has not done."

Tibetan religious writers argue that seeing these two positions-that karma cannot be experienced by another and yet that it can be shared-as contradictory emerges from misunderstanding the nature of moral action. Specifically, it is a problem if one erroneously assumes that the intention of an action and its execution must exist within the same "person." This being so, moral agency is anything but a monolithic solid block: it is, instead, articulated.

One of the most extensive and popular discussions of this topic is to be found in the writings of the nineteenth-century Nyingma yogin Patrul Rinpoché (Dpal sprul rin po che; I808-1887). In his Kun bzang bla ma'i zhal lung (Words of My Perfect Teacher), he discusses the component elements of the act of killing:

The act of taking life is complete when it includes all four elements of a negative action.

Take the example of a hunter killing a wild animal. First of all, he sees an actual stag, or musk-deer, or whatever it might be, and identifies the animal beyond all doubt: his knowing that it is a living creature is the basis for the act. Next, the wish to kill it arises: the idea of killing it is the intention to carry out the act. Then he shoots the animal in a vital point with a gun, bow and arrow or any other kind of weapon: the physical act of killing is the execution of the act. Thereupon the animal's vital functions cease and the conjunction of body and mind is sundered: that is the final completion of the act of taking a life. ${ }^{9}$

7. While the Dhammapada itself has been fully available in the English language since Müller's translation in I870, it was first translated into Tibetan from the Pāli by the twentieth century scholar Gendun Chömpel (Dge 'dun Chos 'phel; 1903-195I).

8. Tsong kha pa, Lam rim chen mo: The Great Treatise on the Stages of the Path to Enlightenment, vol. I, ed. Guy Newland (Ithaca: Snow Lion, 2000), 2 I4.

9. Patrul Rinpoche, Words of My Perfect Teacher (London: Altamira Press, 1998), I03-4 (my italics). 
Patrul Rinpoche's position is part of a mainstream of Tibetan ethical thought that connects with Tsongkhapa's treatment of Asanga's view of moral action in the Lamrim Chenmo, where he condenses Asanga's five-fold scheme into what would become Patrul Rinpoché's four categories:

What is killing? [Asanga's] Compendium of Determinations teaches this in five categories-basis, perception, attitude, affliction, and conclusion. However, you can condense the middle three into the category of attitude and add the category of performance to give a condensed presentation of each of the paths of action in four categories-basis, attitude, performance, and culmination. Such a presentation is easy to understand, and there is no contradiction between it and the intention in Asanga's teaching. ${ }^{10}$

The composite nature of moral action, combined with its basic dependence on intention, means it is amenable after the event to both moral and ritual purification. If intention and execution are distinct components of a moral action, then for example killing a person whilst in no sense intending to do has entirely different karmic consequences from killing a person with the full intention of doing so. By the same token, killing someone and rejoicing in that action means that the karmic consequences of the killing are multiplied; by contrast, it is therefore possible to mitigate the effects of an intentionally negative action, through subsequent profound regret. A past act thus remains karmically (if not historically) available because its intention can later be modified.

This has important ritual consequences: rites given over to confession and regret are seen as actively ameliorating and changing the karmic nature and consequences of past actions. Tsongkhapa himself, for example, was a heroic practitioner of the recitation of the confession rite of the Three Superior Heaps (ltung shags) before the thirty-five confession Buddhas as a means of purifying previously accumulated evil karma.

\section{The Merit of Others}

An extension of this principle is that, since it is possible to look at one's own action as it were from outside, and to either regret or rejoice in it, it is similarly possible to karmically engage with the moral actions of others in the same way. This, of course, is a principle enshrined in the life-story of Śākyamuni Buddha himself. After receiving an opulent meal from a local king, the Buddha was asked by the king to whom he dedicated the karmic fruits of the meal. The Buddha replied that the principal karmic benefits of the meal would not be experienced by the king (who had given the meal mainly as a way of showing off), but by a poor beggar seated at the end of the hall, who had rejoiced at the king's generosity to the Buddha and his monks.

Io. Tsong kha pa, Lam rim chen mo, vol. 2, 218. Pabongka Rinpoche (Pha bong kha rin po che; I878-194I) divides the moral act of killing into three principal components: intention (recognition, motive and delusion), deed, and completion of the act. Pabongka Rinpoche, Liberation in the Palm of Your Hand (Boston: Wisdom Publications, 199I), 443. 
In such cases, intention and action are no longer encapsulated within the same person. Indeed, the karmic process is seen to rest upon a relationship between people, in which one person takes some kind of moral engagement with and responsibility for the actions of another. This relationship of responsibility is discussed at considerable length within the various Tibetan schools. Thus, Patrul Rinpoché discusses the moral consequences of slaughtering a single animal:

Some people imagine that only the person who physically carries out the killing is creating a negative karmic effect, and that the person who just gave the orders is not-or, if he is, then only a little. But you should know that the same karmic result comes to everyone involved, even anyone who just felt pleased about it — so there can be no question about the person who actually ordered that the killing be carried out. Each person gets the whole karmic results of killing one animal. It is not as if one act of killing could be divided up among many people."

The igth/2oth Century Geluk firebrand Pabongka Rinpoché is similarly clear on the topic, but expands its relevance in social terms:

Ordering someone else to do the killing is no different from doing it oneself. A Treasury of Metaphysics [by Vasabandhu] says: "It is all one for armies and so forth: all of them share equally in the deed." ${ }^{12}$ That is, if eight people share in killing a sheep, each of them does not receive a share of the sin: each one receives the full sin of killing the sheep. When a general sends out many soldiers to the slaughter and a thousand men are killed, each soldier commits the sin of killing as many men as an individual soldier is capable of doing; the general, however, gets the full sin of killing all one thousand men. We may set a good example here in the Central Province, but everywhere in Tibet I believe ordained people are making others slaughter cattle for them, claiming, "These are our serfs." But the slaughterer and the person who made him do it each commits the sin of taking a life. If the monk had done the killing with his own hands, only one person would have committed the $\sin ^{13}$

Pabongka Rinpoché's comments are illuminating because they move the discussion of karmic process away from episodic acts of personal merit to the domain of institutional social and economic relations. The implication here is that positions of high institutional responsibility — such as landowner or general, or king-bring with them exponentially enlarged moral responsibilities.

Now it might be argued-in cases such as a general ordering his soldiers into battle- that the relationship was indeed episodic rather than institutional. In other words, that it was because he specifically ordered them to carry out a particular military action that he receives the consequences of it, rather than because he was generally in charge of them. Patrul Rinpoché, however, seems to be arguing more down the second route: for him, a general state of responsibility for another implies an embedded karmic relationship. Consider, for example, his comments on the karmic results of owning a herd of sheep:

The rich as a rule kill countless animals. Of all their livestock, apart from the odd beast here and there, they allow none to die a natural death but have them slaughtered one

II. Patrul Rinpoche, Words of my Perfect Teacher, 104 (my italics).

I2. Vasabandhu's Abbidharmakoșakārikā, f. I34, b4.

13. Pabongka Rinpoche, Liberation in the Palm of Your Hand, 444 (my italics). 
by one as they age. What is more, in summer these very cattle and sheep, as they graze, kill innumerable insects, flies, ants and even little fish and frogs, swallowed down with the grass, crushed under their hooves or swamped in their dung. The negative karmic result of all these acts comes to the owner as well as the beast... Anyone who owns a flock of a bundred or more sheep can be sure of at least one rebirth in hell.'. ${ }^{14}$

In other words, intention is not merely ordinarily attached to the actions of an individual's own body and extraordinarily linked (through conscious rejoicing or ordering of an action) to the acts of others; rather, the individual is seen as being babitually linked to the actions of those persons and animals with whom he or she maintains relationships of responsibility or ownership.

These two modes only appear distinct on the surface: in actuality, they are both relationships in which actor A in some general sense claims responsibility (habitual or intentional) for the actions of actor B. What is interesting here, however, is that this latter understanding clearly extends to a general responsibility for agents as moral wholes, rather than merely claiming responsibility for specific actions carried out by them. A person who owns a hundred sheep is therefore intentionally responsible for them as whole agents, and is therefore responsible for each individual action of those sheep, regardless of his intentional relationship with those actions (he may not intend his sheep to eat frogs, but they do, and he shares in the responsibility). In this sense, hierarchical relations of responsibility and ownership carry with them pronounced karmic consequences.

\section{Institutional Karma and Its Expiation}

Assuming this conception of karma was widely recognized in Tibet, it impliesparticularly for a society that was organized around complex hierarchies of land and labour ownership - that Tibetan institutional life was seen, at least at some level, as being laced through with karmic relations. Indeed, this does appear to have been so in practice. In what follows, I would argue that this particular understanding of the theme of karma gives us a necessary handle on core elements of Tibetan religious culture, in particular rites for the dead, and the special karmic status ascribed to particular relatives; gift relations between prominent lamas as the basis of "special karmic links," and the necessity of exorcistic rites; and the widespread performance of state exorcisms.

Rites performed on behalf of the dead in Tibetan Buddhist areas are, of course, extremely complex, and we have no space here to discuss them in depth. ${ }^{15}$ Treatment of the dead varies profoundly on locale and status-from feeding to vultures in Central Tibet, to funeral pyres in areas such as Ladakh (La dwags), to burial of the corpses of firstborn children within the walls of houses so that they might be

14. Patrul Rinpoche, Words of My Perfect Teacher, IO2-3 (my italics).

15. Martin Brauen, "Death Customs in Ladakh," Kailash 9 (1982): 319-32; Martin A. Mills, Identity, Ritual and State in Tibetan Buddbism (London: Curzon Press, 2003), 223-37; Stanley R. Mumford, Himalayan Dialogue (Madison: University of Wisconsin Press, 1989), chap. Io. 
reborn to the same household again. The rites of the dead often involved tantric empowerment of the deceased; "merit-raising rites"; and, most famously, recitation of the Bardo Tödröl (Bar do thos grol-Liberation Through Hearing in the Intermediate State, usually referred to in the West as The Tibetan Book of the Dead).

In many of these, the central idea was that the consciousness of the dead was present, or made present, at the performance of their own funeral rites, and would ideally be able to hear and rejoice in the performance of those ceremonies. This idea is enshrined in the text of the Bardo Tödröl itself:

If you are going to be born in one of the lower three realms, at the time when experiences of them occur your relatives in the place you have left are performing virtuous rituals free from sin, and gurus and teachers are practicing holy dharma with absolute purity of body, speech and mind, so you will feel great joy on seeing them, and that will immediately cause you to be born in the higher realm, even if you were going to fall into the three lower realms, so it is very helpful. Therefore it is very important not to have impure thoughts but to feel pure devotion without prejudice, so be careful. ${ }^{16}$

However, Tibetan funerary practices involve not only admonitions that the deceased rejoice in the specific merit of rites performed at their funeral, but also the understanding that the performance or sponsoring of rites on behalf of the dead are inherently more effective when carried out by persons that stand in an inheritance or tutelary relationship to the deceased. At funerals, such karmic affinities seem to be twofold: firstly, between the deceased and specific monks and lamas, especially ones from whom the deceased had any kind of tantric bond; and secondly, rites sponsored by the deceased's close kin, using his own possessions. As Mumford notes in his extensive discussion of funeral rites in Gyasumdo:

Tibetan household members send merit (dge ba btang) to their deceased, but they also use the term "shared merit" (dge ba pi ma). ${ }^{17}$ Here they refer to the manner in which household property that is "inherited" by persons who die can be used for merit making on their behalf. Lay persons assert, "Those who share inheritance can share merit." 18

Samdhong Rinpoché identified similar relations as being at the base of shared merit:

We talk about four, sometimes three relations here: if you are a blood relative or a general named relative, you have a joint property, or you have a teacher-taught relationship, then the dge $b a$ can be transferable. If I am related to you by blood, as a brother or by marriage, and one of us dies, then that dge $b a$ can be used by the other person. But you have to dedicate it (sngo ba), then it goes there; otherwise the karmic force cannot be transferred. If you do something wrong, I cannot suffer as a consequence of that; if you do good, I cannot enjoy it. But you can dedicate it to me, and in that case [if] we have some relationship, either blood relationship or property relation or other educationalreligious relation [then I can]. ${ }^{19}$

I6. Francesca Fremantle \& Chögyam Trungpa, The Tibetan Book of the Dead (Boston: Shambhala Dragon Editions, 1987), 79-80.

17. [Sic] dge ba spyi ma.

I8. Mumford, Himalayan Dialogue, 213 (my italics).

I9. Interview with author, March 2I, 2012. 
This is a theme running through many Tibetan exegetical commentaries and practices - that particular individuals often have karmic links to certain specific others in the world around them, rendering ritual and meditative action uniquely effective if carried out along the line of that relationship. When commenting on the "giving-and-taking" (gtong len) meditation practice common to the "mind-training" (blo sbyong) ethical tradition - in which meditators visualize themselves taking the sufferings of others upon themselves whilst giving away their own happiness and good fortune- - the Fourteenth Dalai Lama argues:

To be able actually to transfer one's happiness to others and directly take their sufferings upon oneself is something only possible on very, very few occasions; it occurs when oneself and another individual have a very special relationship based on karmic affinity stemming perhaps from a previous life. ${ }^{20}$

Such close karmic relations are often seen as being created by relations of faith (dad pa) that have been rendered concrete through the giving of offerings- a combination, in other words, of intention and execution. This allows disciples and patrons to actually participate in the virtuous actions of others, especially those seen as morally superior. For Patrul Rinpoché, such participation was amenable almost to an economic, or exchange-based, understanding:

When your sublime teacher accumulates great waves of merit and wisdom through his bodhisattva activities, your own participation with the least material offering or effort of body or speech, or even just your offering of joy at the slightest thing he does, will bring you as much merit as springs from his own unsurpassable intention. Once, there were two men travelling to Central Tibet. The only food that one of them had was a handful of brown tsampa [ground meal] made from beans. He gave it to his companion, mixing it with the other's copious supply of white barley tsampa. Several days later, the better-off traveller said to his fellow-voyager: "Your tsampa is probably finished by now." "Let's have a look," the other said. So they did, and there was still some bean tsampa left. Although they checked many times, the bean tsampa was never finished, so that in the end they had to share all the tsampa equally. Likewise, simply by offering a small material contribution to someone else's positive action, or by participating physically or verbally, you can attain as much merit as they do. Specifically, to serve the teacher's daily needs, to carry messages for him or even just to sweep his room are an infallible way to accumulate merit, so try to do such things as much as you can. ${ }^{21}$

Creating a karmic link to specific teachers through the exchange of gifts has always been an important element of Tibetan Buddhist devotionalism in both legendary and historical accounts. The autobiographies of prominent lamas are replete with journeys to other lamas in order to create "karmic connections," which were seen as essential to ongoing spiritual development. ${ }^{22}$ In the twelfth-century Zanglingma Life Story (Rnam thar zangs gling ma), Padmasambhava's arrival in Tibet was met by five emissaries bearing gifts of gold from Emperor Tri Songdétsen (Khri Srong

20. Fourteenth Dalai Lama, Four Essential Buddhist Commentaries (Dharamsala: Library of Tibetan Works and Archives, 1982), 95 (my italics).

21. Patrul Rinpoche, Words of my Perfect Teacher, I49-50.

22. See for example Richard Barron, The Autobiography of Jamgon Kongtrul (Ithaca: Snow Lion, 2003). 
lde brtsan; 742-c. 800). Demonstrating his magical powers, Padmasambhava threw the gold in the air: "I have no need for your gold, but in order to fulfill the king's aspirations and allow bim to gain merit, I should keep some." ${ }^{23}$ Guru Rinpoché's exhortation is important because it expresses (either as magical history or as literary device) the necessity for aristocratic rulers such as Tri Songdétsen to karmically link themselves to religious gurus as a means to claiming merit, and as a means to establish the state as a religious institution. This was done through the exchange of gifts and offerings.

\section{The Perils of Exchange}

Despite the popular endeavour to create karmic links, such relations are not without their drawbacks. Religious virtuosi in particular often seemed wary of the consequences of such connections. Patrul Rinpoché spends a large quantity of time arguing that the creation of karmic links with disciples and sponsors was fraught with moral danger: indeed, that the religious teacher is much like the military general in terms of the care with which he must approach his relations with others. In particular, he warns against accepting religious gifts, arguing that the recipient must be careful to ensure that their own intention is wholly pure in receiving them:

In the noble lands of India, as a rule, only those that had the highest attainments and were free from all harmful defects had the right to use funds donated to the Sangha [the monastic community], and the Buddha permitted no-one else to do so. But nowadays people learn one or two tantric rituals and, as soon as they can recite them, they start to use whatever dangerous offerings they can get. Without having received the [tantric] empowerments, without having maintained all the samayas [tantric commitments], without having mastered the generation and perfection phases [of tantric practice] and without having completed the requirements of the mantra recitation, to obtain offerings by performing tantric rituals-just chanting the secret mantras perfunctorily like bönpo sorcerers-is a serious transgression. To use these dangerous donations is comparable to eating pills of burning iron: if ordinary people partake of them without having the cast-iron jaws of the generation and perfection phases, they will burn themselves up and be destroyed. ${ }^{24}$

Here then, Patrul Rinpoché argues that the normal imperfections of most tantric practitioners - even very advanced ones - make them vulnerable to the dangers that come with accepting the gifts of disciples and sponsors, donors whose own imperfections are transferred through the gift, much like the brown tsampa being mixed with the white in his analogy. The implication here is that the receipt of gifts—and the consequent status as master of offered property — carries with it karmic consequences that rely less clearly on precise intention.

This is a common concern in Tibetan social life, where accepting people's hospitality creates an involuntary karmic link between recipient and donor which places

23. The Lotus Born: The Life Story of Padmasambhava, trans. Erik Pema Kunsang (Boston: Shambala Press, 1993), 6o (my italics).

24. Patrul Rinpoche, Words of my Perfect Teacher, Io9 (my italics). 
the recipient under the power of the donor in particular ways. French, for example, records a Tibetan monk's tale of a group of monks and nuns travelling through the Namru area, who were accosted by robbers who demanded all their food. One nun refused, fearing that their party would starve on the roadside without provisions. However, an ascetic tantric practitioner in the party told the nun to give them all the party's food. Once the robbers had eaten, they mounted their horses, but the tantrist then pronounced wrathful mantras that paralysed both robbers and their horses. The tantrist kept them in this state for three days until they were ready to repent. ${ }^{25}$ In my own experience, many Ladakhis and Tibetans expressed fear of eating the food of certain houses lest their owners-who were suspected to be witches - thereby gain control of their life force. ${ }^{26}$

This is not merely a popular or "folk" concern, but similarly influenced affairs at the elite level. In his autobiography, Jamgön Kongtrül Lodrö Tayé ('Jam mgon kong sprul Blo gros mtha' yas; $1813-1900)$ comments on how the religious offerings that came his way from his growing prestige caused a gradual lessening of the visionary capacities he had maintained in his youth:

The greater my distractions became, the more my positive tendencies were eclipsed and my confused tendencies encouraged. Because it was necessary for me to be involved in all kinds of contamination due to articles offered to me in faith, especially the contamination associated with deceased individuals, from this time on the clear and visionary experiences of my earlier life became obscured; the positive signs in my dreams stopped, and I dreamed of numerous bad omens. Even the vigour of my experiences and realization in meditation has suffered accordingly, and I find that I am quite dismayed at having had to engage so recklessly in such negative and contaminating activities. ${ }^{27}$

Similar concerns are raised by the Fifth Dalai Lama (I617-1685) in the Dukula, his "exoteric" autobiography. Referring to his youthful days of religious training, he comments:

At a gathering with Lingmé Zhabdrung, Zhalngo and many others, Tawon Choje said: "All the Mongols were conquered by the king of Chakhar, and should any invitation come from him it would be better for you to go." He continued giving advice on how to react and prepare ourselves. However, I thought: "What is the point in going to such a place to waste this precious human existence that one obtains very rarely!" At that time, I admired lives of former savants and yogins. I wished I could go to India and study Buddhism there. If this was compared with those who put on a pretense of virtue, my intention was quite good. Later, however, I was so consumed by the wealth given by the faithful that these aspirations never returned. ${ }^{28}$

25. Rebecca French, The Golden Yoke: The Legal Cosmology of Buddhist Tibet (London: Cornell University Press, 1995), I04-5.

26. Mills, Identity, Ritual and State in Tibetan Buddhism, I73, 20I. See also Giovanni da Col, "The Poisoner and the Parasite: Cosmoeconomics, Fear, and Hospitality among Dechen Tibetans," Journal of the Royal Anthropological Institute, n.s., I8, suppl. si (2012): 175-95.

27. Barron, The Autobiography of Jamgon Kongtrul, 77.

28. Samten Karmay, The Illusive Play: The Autobiography of the Fifth Dalai Lama (Chicago: Serindia, 20I4), 8I (my italics). 
The matrices of religious respect and offering that surrounded high lamas in Tibet were thus seen to be fraught with moral peril-danger which linked people together in manners far more complex than a simple individualistic interpretation of the Buddhist doctrines of karmic retribution might imply. In particular, the act of gift-giving was seen as a legal and metaphysical connection that bound two people in a way that, for example, simply rejoicing in another's actions did not.

If religious offering was as perilous to receive as Patrul Rinpoché implies, such dangers could only be offset by the constant maintenance of moral and ritual purity, or by the regular performance of exorcistic rites. As with many Nyingma lamas, a particular ritual support for Jamgön Kongtrül was the performance of Vajrakilaya (Rdo rje phur bu) rites, a regular feature of his religious life. Vajrakilaya was a prominent Nyingma deity who has the rather singular iconographic form of a ritual dagger with a winged garuda bird as handle. ${ }^{29}$ The deity is invoked to "nail down" spiritual obstructions such as those caused by impure offerings.

Jamgön Kongtrul was not alone in using such rites: indeed, the invocation of exorcistic rites constituted a standard feature of Buddhist monastic life in Tibetan areas. Such rites were generally referred to by the term torlok (gtor logs) - that is, rites using a torma (gtor ma-votive offering) to expel or turn back inimical influences. While Nyingma ritualists such as Jamgön Kongtrul favoured the Vajrakīlaya cycles, other schools emphasised other traditions: the Gelukpa, in particular, practiced those cycles surrounding the wrathful Buddha Yamantaka and his associated protector deity Yāma. ${ }^{30}$

\section{The Karma of Kings and States}

The hierarchical nature of karmic responsibility and the perils involved in gift exchange applied equally to Tibetan understandings of the moral formation of their central institutions - whether of the state, of wider civil society, or of religious institutions. Indigenous understandings of history, society and religion have always been discussions of the great and the good, and people's relationship with those exemplars. Post-dynastic Tibetan "political theory" clearly presented the centre as leading and the periphery as following, a view at odds with the more sociological interpretive tendencies of many modern scholars. In a recent retrospective essay on the history of the Dalai Lamas' government, the Ganden Podrang (Dga' ldan pho brang), Chung Tsering, the Minister for Education of the Tibetan Government-in-Exile in Dharamsala, commented:

It is a general tendency among modern historians to judge events, good or bad, of a particular king or dynasty on the basis of the general political background of the period and not whether they were in fact initiated by that particular ruler or not. Personally

29. Namdrol Rinpoche, The Practice of Vajrakilaya (Ithaca: Snow Lion, 1999); Dudjom Rinpoche, The Nyingma School of Tibetan Buddhism (Boston, MA: Wisdom Publications, 199I).

30. Mills, Identity, Ritual and State in Tibetan Buddhism. 
I think this is wrong. According to Tokjö Rinpoché Paksam Trishing,, "If the ruler is learned, he will love wisdom and become himself accomplished in the same. If the king is foolish, he will be extremely ignorant; if deceitful, he will be extremely deceitful; if atrocious, he will be extremely atrocious. If the king is brave, he enjoys and befriends war and engages in it. Thus, the manner in which kings rule their kingdom, his subject people will also follow him in the same manner." On this the Thirteenth Dalai Lama (I876-I933) further remarked, "Just as the ruler or king engages in explication, debate and composition, his subject people also follow him and engage in the same things. Likewise if the king engages in evil works, his subjects will also engage in evil things. Even if the king is a warrior and loves war, the people will also enjoy war just like him. In short, whatever the king or ruler does, his subjects citizens will also do like him." (Excerpted from "Code of Regulations for the Tse School Students," Collected Works of the Thirteenth Dalai Lama, Cha, bca' yig) $)^{32}$

This vision of monarch-subject relations is more than simply a question of representation. There is, rather, an implication that the sovereign is somehow the karmic primum mobile of social change rather than simply one political player amongst many. Thus, in the fourteenth century Clear Mirror of Royal Genealogies, the fate of the kingdom was intimately linked to the body of the king, as in the depiction of Tri Songdétsen's first meeting with the Abbot Sāntarakșita:

The king, without even binding his girdle (sku rags) around his body, took hold of one ful bre [measure] of gold-dust and hurried to arrive at the abbot's reception. It induced the abbot to declare: "King! The fact that you are wearing your turban on the head means that the upper (stod) [i.e. Western, i.e.] Mnga' ris, the secular law will be abolished as much as the size of your hat. The fact that you are wearing shoes (chag) on your feet, shall indicate that in the lower (smad) [eastern] Mdo Khams the secular law will be abolished as much as the size of your shoe. The fact that the king has not fastened his girdle around his body shall indicate that the king's law is in fear of being quickly abolished here in the central [part of Tibet, i.e. Dbus Gtsang]. However, by offering a present of precious stones, it will still be possible to practice Buddhism. ${ }^{33}$

For writers such as the sixteenth-century Nyingma yogin Zhikpo Lingpa (Zhig po gling pa; $1524-1583$ ) - here describing his own political patron, the local ruler Döndrup Rabten Gyalpo (Don grub rab brtan rgyal po)—-kings are seen as existing at the centre of a state's karmic economy:

31. Rtog rjod rin po che dpag bsam kbri shing.

32. Chung Tshe ring, "Bod gzhung dga' ldan pho brang phyogs las rnam rgyal dbu brnyes pa'i brgyud rim dang / dbu brnyes rjes kyi grub 'bres 'ga' zhig dmigs bkar du gleng ba phyi rabs gzhon nu'i gdeng 'jog/.” In Department of Information and International Relations, Bod mi'i kbrims mthun gzhung dga' ldan pho brang dbu brnyes nas lo 360 'khor ba'i bka' drin rjes drin dang ma 'ongs mdun bskyod kyi kba phyogs (Dharamsala: Narthang Press, 2002).

33. Per Sørensen, Tibetan Buddhist Historiography: The Mirror Illuminating the Royal Genealogies (Wiesbaden: Harrassowitz Verlag, 1994), 367. 
The protégé of the Lord Mañjuśrī ... adorned with wish-fulfilling jewels and [endowed with] competence in both religious and secular affairs, is at the centre of the ocean of merit flowing from the opening of the lotus of the merit of sentient beings in the land of snows in the merciful illumination of the Three Jewels. ${ }^{34}$

Zhikpo Lingpa clearly felt this principle applied more broadly to all forms of secular and religious authority. In one of his terma (gter $m a$ ) prophecies concerning the flooding of Lhasa, Guru Rinpoché is depicted explaining the relationship between the individual well-being of secular and religious rulers (and their temples) and the general karmic well-being of the Tibetan people:

The King's authority is [due to] the merit of beings, however it was the Jina Śākyamuni who established all beings on the plane of happiness. Although the Jina established beings in [the] happiness [of his teachings] in India, China, Za hor and so on, the symbols of body, speech and mind, temples and so on are [produced through] the power of the merits of beings, and that being so, the time when temples and holy symbols are constructed is the time when the merits of beings are at their highest. When offerings and circumambulations are made at these temples, the merit is medium, and finally, when these temples fall, the merit of beings will be greatly diminished. ${ }^{35}$

Strange though this may seem to secular political thought, the idea that large scale political and economic transactions - in particular those associated with kingshipmight constitute karmic relations, and thus imply possibility of ritual and moral pollution that required careful purification, is reasonably widespread. Indian systems of kingship have also presented moral conundrums for the collective understanding of the good. As Heestermann famously noted, the figure of the king stands astride a profound moral ambiguity at the heart of Indian political power:

The texts are unanimous in assigning the protection of the people and the maintenance of the order of the world or even of the whole universe to the king. He is then easily exalted to be the world order itself, dharma incarnate, or at the very least equal to ten wise men learned in the Veda. So whatever the king does is the norm and all dharma is subsumed in the rajadharma. A kingless country therefore comes to ruin and one should not settle in such a place. But on the other hand the king-not just the unrighteous king, but the king in general - is roundly abominated. That instead of being exalted as the benign protector of his people he is simply the "eater" of the people who devours everything he can lay hands on, is already a cliché in the Vedic prose texts. Later texts enlarge upon this point by stating for instance, that ten slaughterhouses equal one oil press, ten oil presses one tavern, ten taverns one brothel, finally giving the ultimate prize for wickedness to the king who is as evil as ten brothels; or the king is put on a par with a butcher who keeps a hundred thousand slaughterhouses. It is then hardly surprising any more to find him mentioned together with other calamities like floods, fires and thieves. ${ }^{36}$

34. From Zhig po gling pa'i bka' 'bum, vol. Ta, cited in Matthew Akester, "The 'Vajra Temple' of gter ston Zhig po gling pa and the Politics of Flood Control in i6th Century Lhasa," Tibet Journal 26, no. I (200I): 2I (my italics).

35. Ibid., I5.

36. J. C. Heesterman, "The Conundrum of the King's Authority," in Kingship and Authority in South Asia, ed. J. F. Richards (Madison: University of Wisconsin, 1978), 2. 
At one and the same time, therefore, in the Indian context, the king is both an "eater of men" and the principal fulcrum in the moral constitution of the worldly human universe. In the Tibetan accounts on the Empire period, regicide-even the killing of a corrupt and venal king-was felt to lead automatically to the collapse of the kingdom and the scattering of its wealth and prestige (a theme implied much in post-dynastic discussions of the fragmentation of the Empire that followed the assassination of the anti-Buddhist king Langdarma [Glang dar ma; r. 838-842]); more than this, however, it removed the cornerstone that protected the people and the dharmic law.

Tibetan understandings of the state contained within them a greater conundrum even than that identified by Heesterman. The tension between the king as simultaneously virtuous protector of the law and dangerous enactor of kingly violence is portrayed most clearly in the developing post-dynastic narratives surrounding Tibet's first Buddhist king, Songtsen Gampo (Srong brtsan sgam po; c. 605-649), famed for creating illusory manifestations of himself as thousands of bloodied victims of the king's law, in order to magically guide Tibetans towards virtue through fear. ${ }^{37}$

Similar principles seem to have applied to the Ganden Podrang state, founded under the Fifth Dalai Lama in the seventeenth century. Taking as its legitimating figurehead a Buddhist lama rather than a secular king, the patterns of exchange and hierarchy that rendered the kingship morally suspect seem to have made the religious rule of the Dalai Lamas - whose position as bodhisattvas and divine Buddhist manifestations was presented as the basis of their claim to rule from Lhasa-uniquely delicate in constitutional terms. How were these two visions of the Dalai Lama as head of state - the priestly bodhisattva and the kingly "eater of men"- to be resolved?

There seem to have been several answers to this question. Here, we shall look at three mechanisms by which the moral purity of the Dalai Lama as head of state was maintained within the inevitable moral quagmire of the state itself: (i) the legal separation of the Dalai Lama as sovereign from the wider state; (ii) the ritual protection of the Dalai Lama as sovereign, and; (iii) the constitutional function of apotropaic temple-building.

\section{The Separation of State and Sovereign}

In her examination of the early constitutional documents of the Lhasa state under the Dalai Lamas, Ishihama notes how the Fifth Dalai Lama's regent, Sanggyé Gyatso (Sangs rgyas rgya mtsho; $1653^{-1705}$ ), saw the Dalai Lama as a fundamentally religious figure that nonetheless stood at the heart of state affairs, a combined requirement that led to a division of labour between the Dalai Lama and his political protector or "king," the Mongol princeling Güshri Qan (1582-1655):

It goes without saying that [the king] must implement [policies] by wrapping the commands of His Incomparable Holiness [the Dalai Lama] around his head like a cloth

37. Martin A. Mills, "Ritual as History in Tibetan Divine Kingship: Notes on the Myth of the Khotanese Monks," History of Religions 51, no. 3 (2012): 219-20. 
without discarding them (i.e. always bearing them in mind); furthermore, he should not make decisions by himself on matters of an important nature, while in the case of very bad matters or matters that are not of importance he should settle them himself because reporting every single such matter will disturb the [Dalai Lama's] meditation. ${ }^{38}$

The generality of this inclination by the elite Tibetan classes in Lhasa has been widely acknowledged:39 whilst certain Dalai Lamas-such as the Fifth-became deeply involved in governmental affairs, this was generally regarded as unseemly and inappropriate. While the Dalai Lamas' religious blessing and influence were seminal to the state itself, it should not be sullied by the "very bad matters" that state life often entailed.

This is a governmental axiom which dates from the very first moment of the Ganden Podrang state itself, when it changed from being a religious estate, or labrang (bla brang), to being a government with Güshri Qan's gift of the conquered lands of Tibet to the Dalai Lama's estate as a "religious offering." However, the lands of Tibet were not gifted by Güshri Qan directly to the Dalai Lama himself, as is often supposed, but to Sönam Chöpel (Bsod nams chos 'phel), his manager and regent. ${ }^{4 \circ}$ This subtle but important distinction meant that the Dalai Lama was placed above the relationship between "patron and preceptor," thus partially immunizing the young bodhisattva from moral embroilment with the terrible bloodshed involved in Güshri Qan's conquests. The new ruler was obviously troubled by this element of his relationship with Güshri Qan. As he wrote of the qan's gift in his autobiography:

If it were that I had been beneficial to the king in a previous birth, and now he wanted to pay me back, so be it. Otherwise, if one infers the way in which he intended things, I had no confidence in helping him either removing obstacles in his life here or leading him to heaven hereafter. It was a heavy burden of responsibility, and it would be hard to repay his kindness, even in an aeon of time. This kind of affair would not be beneficial for practicing religion. However, if there were an overall leadership in place in Tibet, there would be a time of peace. It occurred to me that this (overall leadership) would in fact help the Sakya, Karma and Nyingma schools from not completely disappearing. ${ }^{4 r}$

As it turns out, this constitutional separation was indeed only a partial remedy, since the Dalai Lama stood in the middle of diametrically opposed constitutional forces:

38. Yumiko Ishihama, "On the Dissemination of the Belief in the Dalai Lama as a Manifestation of Avalokiteśvara," Acta Asiatica 64 (I993): 4I-42. Republished in A History of Tibet, vol. 2, ed. Alex McKay (London: Routledge Curzon, 2003), 538-53.

39. Dawa Norbu, China's Tibet Policy (London: Curzon, 200I), 80-82; Charles Bell, Portrait of a Dalai Lama: The Life and Times of the Great Thirteenth (London, 1931; repr., Boston: Wisdom Publications, 1987), 19I; Luciano Petech, China and Tibet in the Early I8th Century (Leiden: Brill, 1950), 218.

40. Ishihama, "On the Dissemination," 39; Shakabpa, Bod kyi srid rgyal rabs (Political History of Tibet), vol. I (1976; repr., Kalimpong, 1986), 425 n. 32; Samten Karmay, "The Fifth Dalai Lama and the Reunification of Tibet," in Lhasa in the Seventeenth Century, ed. Francoise Pommaret (Leiden: Brill, 2003), 73.

4I. Za hor gyi bande Ngag dbang blo bzang rgya mtsho'i 'di snang 'kbrul pa'i rol rtsed rtogs brjod kyi tshul du bkod pa du kuu la' i gos bzang las glegs bam dang po, vol.I (Delhi, 1985), f. 217. Translation from Karmay, The Illusive Play, 166-67. 
whilst his religious purity and thus authority were guaranteed by his maintaining a separation from exercising direct governmental power, at the same time this very authority meant that his personal involvement in the affairs of state was constantly demanded by political allies and the people. In the case of the Fifth Dalai Lama, he oscillated between direct helmsmanship of the government and withdrawal, leaving the government in the hands of a regent no less than five times. ${ }^{42}$ Indeed, the fact that he could withdraw - an event that was always couched in religious terms, as an opportunity to purify and meditate-allowed his last regent Sanggyé Gyatso to conceal the ruler's death for fully fifteen years.

This kind of disjunction between head of state and government is far from unusual, despite its apparent unfamiliarity. The modern British state-itself a parliamentary monarchy-works in a similar way: by royal prerogative, the powers of the monarch are devolved to the elected Prime Minister and his Cabinet, who only consult the monarch on matters of national importance. It is only when these lesser offices are compromised (such as by elections, hung parliaments, etc.) that the sitting monarch's latent powers become manifest through his or her dissolution or calling of parliaments and so forth. Just like the Dalai Lamas, this allows the monarchy to remain largely immune to the moral quagmire of parliamentary politics, and thus maintain her sovereign authority.

\section{The Ritual Protection of the Sovereign}

The second solution to the moral conundrum of the Ganden Podrang state was the regular performance of protective rites focused on the person of the Dalai Lama himself. Again, the young ruler's direct involvement with matters of state was often deemed to be personally dangerous to him. In the months following Güshri Qan's gift of Tibet to the Great Fifth, for example, the Dalai Lama suffered a chronic cough that meant he could not speak. Despite his initial "immunisation" from the sponsor-offering relation described above, his Nyingma teacher Zurchen Chöying Rangdröl (Zur chen Chos dbyings rang grol; I604-I669) advised him that the cough was a result of the "impurity of broken vows" that had come from his alliance with the Mongol chieftain against the King of Tsang (r. I630-I642), in particular his performance of violent tantric rites on behalf of his ally in I64I. ${ }^{43}$

As a temporary means to remedy the situation, Zur provided the young Dalai Lama with protective amulets. Subsequent to this, the Fifth Dalai Lama dreamt of performing the Nyingma rite to Karmaguru - a form of Vajrakīlaya. The Dalai Lama then woke to find his cough much better. As a consequence of the dream, he took to wearing a ritual dagger in his belt (despite the disapproval of his Gelukpa attendants), and instituted the Karmaguru ceremony as a principal state ceremony,

42. Luciano Petech, "The Dalai Lamas and Regents of Tibet: A Chronological Study," T'oung Pao 47 (1959): 368-94.

43. Samten Karmay, Secret Visions of the Fifth Dalai Lama (London: Serindia, 1993), I5. See also The Illusive Play, I54 for a description of another rite carried out by the Fifth of behalf of Güshri Qan. 
to be performed by the monks of Namgyal monastery in the Potala Palace, and designed to "maintain the welfare of the people of Tibet." ${ }_{44}$ The rites were therefore seen to unify in one action the protection of both ruler and ruled.

\section{The Necessity of Apotropaic Temple-Building}

Last, but by no means least, the conundrums of the state's moral existence were abrogated by building a series of temples, both in recompense for the morally negative actions of the state and as a means to purify them. This is a tradition that seems to have been solidly established long before the time of the Ganden Podrang: the thirteenth-century Victorious Banner Explaining Religious History (Chos 'byung chen po bstan pa'i rgyal mtshan) of Deu José (Lde'u jo sras) records those imperial Tibetan temples built for the purification of sins:

The so-called "additional eight profits" (kher) are as follows: eight Tibetan generals built eight great temples to cleanse their sins. They carried away all of their sins, and this being greatly profitable, they are called the eight "profits" (kher).

Thus [I] Gnyer Stag-btsan Stong-gzigs built Gling Khri-rtse Temple to purify the sins of doing battle with China.

[2] Spa-tshab Stong-pa and Stong-'byams built Mandharaba Temple to purify the sins of destroying the four garrisons.

[3] Khri-gsum-rje Stag-snang built Brag-dmar Dka'-chu Temple to purify the sins of doing battle with China, the maternal uncle (zhang-po Rgya).

[4] Cog-ro Skyes-bzang Rgyal-'gong built Mkhar-stod Gnam-ru Temple to purify the sins of incest/fratricide (dme byas).

[5] Khyung-po Spu-stangs Ring-po built Stod-lung Lum-pa Temple to purify the sins of having served as a Hor general.

[6] Rgya-ro Long-gzigs built Stod-lung Mong-hra Temple to purify the sins of having served as a general.

[7] Lce Khri-bzangs Lha-byin built an astrology temple (rtsis kyi lba-kbang) to purify the sins of having served as a general.

[8] Sbas Rgyal-to-re Stag-snang built the guardians of Khrom-sna Lha-lung to purify the sins of having slandered the innocent Bran-ka Dpal gyi Yon-tan.

In this way eight very sinful men had all of their sins carried away by building eight temples, and they are thus called the eight "profits" (kher). 45

Similarly, in the Prayers of De ga g.yu mtshal, commemorating the 822 peace treaty between Tibet, China, Nanzhao and the Uyghurs, the sins of the war were purified by the building of a treaty temple:

Through the construction of the Treaty Temple on the plain, and through blessings and merit of the governors of the realm of Mdo-gams, who present gifts and offer to the

44. Ibid., 3I.

45. Quoted from translation in Brandon Dotson, "Administration and Law in the Tibetan Empire: The Section on Law and State and Its Old Tibetan Antecedents" (DPhil Thesis, University of Oxford, 2007), 230-3I. 
three jewels, the misdeeds of the divine emperor, the lord, together with his ministers and retinue, are purified. ${ }^{46}$

A similar logic seems also to have stood behind the building of the so-called "Gesar Lhakhang" on mount Bhamari, the third of Lhasa's principal hills. Constructed in 1792 , the temple was built to commemorate the recently finished war with the Nepalese Gorkha kingdom to the south, a war that was carried out in defence of Tibet, but under Chinese military command. The temple was commissioned by the Chinese ambans in Lhasa, and dedicated to the Chinese god of war and justice Guan Di 關帝, whom the Tibetans equated with the legendary king of Ling, Gesar. ${ }^{47}$

In the case of the Great Fifth, however, this principle had more dramatic consequences that stood at the very heart of the Ganden Podrang state building process. The choice of Marpori (Dmar po ri) Hill in Lhasa for the new Potala palace upon the founding of the new Ganden Podrang government in the I640s had important religious connotations regarding the Dalai Lama's claim to be a manifestation of Tibet's patron deity Chenrésik (Spyan ras gzigs). ${ }^{4}$ Marpori was the site of the first Tibetan temple to Chenrésik, and also the site of the palace of Tibet's great emperor Songtsen Gampo, who had been widely renowned as the iconic manifestation of Chenrésik since the IIth century. The statue of Chenrésik at the old temple at Marpori was revered throughout Tibet as one of the great relics of Songtsen Gampo's rule. In 1617 , in a bid to bring political aid to the beleaguered Lhasa Valley during the long civil war that haunted central Tibet during the sixteenth and seventeenth century, the governor of the Lhasa Valley area gave the Marpori statue of Chenrésik to the Tümed Mongol leader Chökhor Qan as a means to support their military campaign. ${ }^{49}$ Over the next thirty years, the statue was taken from one battlefield to another, eventually standing at the head of Güshri Qan's armies as he faced the King of Tsang at Shigatsé in 1642.

While the statue had clearly represented a crucial symbolic bulwark in the Ganden Podrang's war against Tsang, and was an essential component of Lhasa's religious heritage, its involvement in the war clearly troubled the Fifth's teacher Lingmé Zhapdrung (Gling smad zhabs drung Dkon mchog chos 'phel; I573-I644). In order to ameliorate the situation, he suggested to the Fifth that, in order to purify the sins of Güshri Qan and the regent, a temple dedicated to practices relating to the mantra of Chenrésik should be erected on Marpori prior to the statue's return..$^{\circ}$ The temple Lingmé Zhapdrung recommended would eventually become the White Palace of the Potala, the Dalai Lama's primary seat of government. In 1645 , once the palace

46. IOL Tib J 75I, 11. 35aI-35a2; Dotson, “Administration and Law," 235. See also Matthew T. Kapstein, The Tibetans (Oxford: Blackwells, 2006), 78.

47. Knud Larsen \& Amund Sinding-Larsen, The Lhasa Atlas (London: Serindia, 200I), I46.

48. Ishihama, "On the Dissemination."

49. Per K. Sørensen, "Lhasa Diluvium," Lungta, I6, no. I (2003): I20 n.79; Dung dkar Blo bzang 'Phrin las, The Merging of Secular and Religious Rule in Tibet (Beijing: Foreign Language Press, 1991), 62.

50. Za bor gyi bande, f. I18a4-6; see also Ishihama "On the Dissemination," 53. 
was completed, the Chenrésik statue was returned from Tsang to Lhasa, and reinstalled on Marpori, the occasion being marked by a grand banquet. ${ }^{5 \mathrm{I}}$

\section{Conclusion}

The sources reviewed above are diverse and, in religious, political and historical terms, heterogeneous, drawn from more than six centuries of Tibetan history and several different polities and schools of Buddhist practice. This diversity is deliberate, pointing less towards a consistent culture or "theory" of communal karma in Tibetan societies, and more towards a general preoccupation with the moral nature of institutional responsibility and the consequences of exchange, one that was and is couched (at least at the elite level) in karmic terms.

What is also evident from the above is that such concerns had differences of emphasis and nuance (thus, for example, Nyingma sources seem to place greater emphasis on these issues than others, and to place greater emphasis on the fact of exchange rather than the explicit intention). At the same time, all of them presented a view of moral and karmic action that was intrinsically social and interlinked rather than individualistic.

In this regard, intentional economic transactions and ongoing legal relations were seen as having a necessary and unavoidable karmic dimension. In ritual terms, this can be seen in the recognized karmic linkages asserted between those sharing inheritance, and in the programmatic formation of "karmic links" between religious teachers and disciples. Within Tibet's profoundly hierarchical religious culture, this principle was attended by certain moral asymmetries: whilst many individuals assiduously sought out exchange relations with what they saw as their moral and spiritual superiors, many of those very superiors either felt (or were at least advised to feel) a certain reluctance in uncritically accepting the offerings of disciples, sponsors, and petitioners. This caution was couched around with images of impure commensality, but focused on the potential spiritual corruption that attended such offerings.

Similar concerns appear to have attended Tibetan understandings of Buddhist governance: the moral consequences of state action (particularly, and rather obviously, surrounding military conquest) were seen to undermine the purity of the Dalai Lamas as religious authorities, and required counterbalancing on both the constitutional and ritual stage. The various mechanisms of separation-constitutional, economic, ritual and architectural-outlined above imply that Tibetans were sensitive to the conundrum implied by the idea of religious, rather than merely aristocratic, rule. However, their responses to it were not "constitutional" in the formal or ideological sense, but rather practical ritual responses to problems that were perceived to be real and historical, if conceived in terms of karma and spiritual pollution. In constitutional terms, it necessitated a complex balance of involvement

51. Za hor gyi bande, ff. 126bi-I27br; Zahiruddin Ahmad, The Life of the Fifth Dalai Lama (Delhi: Aditya Prakashan, 1999), I40-43. 
and detachment between the Dalai Lama and his own government, just as the righteous incarnate balances his responsibilities to his disciples and estate with a need to withdraw, meditate and purify.

Mots-clés : Karma commun, l'échange, Ganden Podrang, Dalai Lama, gouvernement, habileté politique. 